\title{
17 \\ IRAN \\ From the ancient world of Elam to modern science communication
}

Seyede Zahra Ojagh and Zarrin Zardar

\section{Introduction}

As the inheritor of Elam's civilisation (2700-539 BCE), Iran has a long history in science. It is located in the Middle East, and has 81 million inhabitants. Gondishapur, the intellectual centre of the Sassanid Empire, dates back to the late third century $\mathrm{CE}$, was a remarkable achievement of the Iranian civilisation. Philosophy, astronomy, pharmacy and medicine were some of the scientific fields studied in Gondishapur. It was an international science centre that brought together scientists from around the world. The Greek, Indian and Iranian scholars communicated in Gondishapur in a way that made it a big multilingual university. Islam first came to Iran between 637-651 CE, and subsequently it experienced further brilliant scientific development for more than five centuries. Gondishapur, along with other scientific centres such as Baghdad and $\mathrm{Al}$-azahar, were centres for knowledge production, communication and education. After the Moguls' invasion about 1219 CE, the Islamic civilisation in Iran started to decline and this continued until the country faced modern Western science in the 19th century.

The acquaintance of Iranians with modern science dates back to the Qajar era in the early 19th century when the Iranian army was defeated by the modern weapons of the Russians. The government responded to this failure and its subsequent misery by dispatching students overseas to study in 1811. Then followed the development of the printing press in 1837 and the establishment of the first Iranian modern high school, Dar-ul Fonoun in 1852, which indicated the initiation of the first period of modernisation in Iran (Mohsenian-Rad, 2013; Abrahamian, 2008). Subsequently, translated 
texts and the graduates of the Western universities paved the way for the progress of modern science in Iran. Among these people, Abdul Rahim Tabrisi, known as Talebov, can be considered as the first writer addressing public knowledge and the first science communicator in Iran. In 1892, influenced by the book Emile by Jean-Jacques Rousseau, he wrote the book Ahmed, explaining modern science in plain language to the general public.

The advancement of modern science was accelerated by the establishment of the first Iranian university in 1934, and soon diverse fields of science and technology were developed in Iran. Today, over 4 million students are studying in 2,569 academic centres in Iran (Iranian Higher Education Research Institution, 2018).

The first signs of attention to science communication can be found in a few works of journalists who wrote about the advancements of the Western community for the literate urban audience in Iran in the second half of the 19th century (Ojagh, 2012). However, in planning for the nation's scientific development, policymakers rarely considered a role for the public and the participation of citizens in science.

Overall, more science communication activities in Iran were carried out after the Islamic Revolution. At this point, the government's approach to modern science changed and applied science took priority over the humanities, critical and basic science. Islamisation and the application of science in Iran became the government's agenda. Since 1979, the government's policy on science has been focused on education and on encouraging research rather than the public communication of science. Science communication was first recognised in the government policy in 2010 (Supreme Council of the Cultural Revolution, 2010). Scientific societies and individual scientists led the way, setting up foundations, museums and activities to encourage public interest in science. Interest in science communication has grown enormously in recent years thanks to widespread access to international events through the internet, but it is still a new and developing field.

The government thought that the development of science communication was indispensable for both the scientific community and the public because science and technology can help the development of the society only when they are turned to address society's concerns. These subjects need to be discussed at all levels among the stakeholders to reduce the costs and risks of the development of science and technology. Society's needs and expectations should be considered when policymakers are determining the priorities of the development of science and technology, as such an environment will let new scientific and technological issues enter the public sphere and become part of social debates. 
There have been efforts from both state and civil institutions to link science and society. However, these experiences have never been systematically analysed and documented, which is why there is not much knowledge of the status of science and technology communication in Iran.

In this chapter, we have attempted to present a relatively comprehensive summary of modern science and technology communication in Iran by collecting evidence from a variety of sources, including academic papers, books, interviews with experts and stakeholders as well as online databases. For this purpose, the experience of science communication in Iran has been considered from three perspectives: policymaking, practical experiences of science communication, and science communication at universities. This exploration is followed by a discussion of the status of science communication in Iran.

\section{Science and technology policymaking in Iran}

Science and technology policymaking in Iran can be discerned from two categories of documents: a) medium-term five-year development plans in which science and technology have been considered as one of the sections or sub-sections; and b) upstream documents that include the three major legislative documents in this area and outline the country's major strategies.

The first basis for science and technology policymaking can be seen in Iran's medium-term plans, with the starting point dating back to the country's first development plan in 1948. Science and technology were implicitly considered by policymakers in each of the six development plans in the years 1948-79 leading up to the Revolution. All plans had a chapter on education but none ever mentioned communicating science to the public. The country wanted to develop infrastructure and industry and needed educated and skilled people. Thus, many programs were established to increase functional literacy.

Following the eight-year war between Iran and Iraq (1980-88), science and technology were considered in limited and dispersed legislative articles or notes in the first and second development plans in the post-Revolution period. In terms of their content, the plans focused mostly on the development of education (State Management and Planning Organisation, 1990; State Management and Planning Organisation, 1994). However, the turning point of attention to science and technology in policymaking was in the third post-Revolution development plan, where the development of research, innovation and technology was one of its main goals (State Management and Planning Organisation, 2000). This change in policymaking seems to be due 
to a change of personnel, a rotation of the political elite and the coming to power of the so-called reformist government. Eight years after the war, under stable economic conditions, knowledge-based development was now on the agenda of the government. It demonstrated its intentions by increasing the number of research institutions and developing new academic disciplines and knowledge enterprises. The aim was to acquire leadership status in political and economic competitions in the Middle East.

Following this trend, the fourth development plan (2005-09) focused on increasing scientific production and the promotion of Iran's ranking in knowledge production, and making progress towards a knowledge-based economy. It also emphasised the quantitative and qualitative development of education, especially academic education (State Management and Planning Organisation, 2004). Then the conservatives returned to power and dissolved the Management and Planning Organisation. While the fifth development plan (2011-15) pursued the same goals as the fourth, its policies were too ambiguous to be practicable (Vice President for Strategic Planning and Oversight, 2010). For instance, it introduced the evolution of the humanities with regard to the four criteria of Islamisation, localisation, modernisation and efficiency, but it did not specify how this was to be carried out or the mechanisms of implementation.

Then the Rohani administration took office and the Management and Planning Organisation was revived. The sixth development plan (2016-21) focused on specific scientific and technological priorities and sought to return to the path of the fourth plan. The aims were now the promotion of the scientific ranking of Iran by the development of research, the production of goods and services based on science and technology, and the enhancement of international scientific-research interactions (State Management and Planning Organisation, 2017). In general, the approach of the development plans to science over 32 years has shifted from a focus on the development of general education and higher education, to a new prioritisation of research, the creation of science and its application in the knowledge-based economy. These policies encountered serious problems on the path to implementation, an issue that greatly affected the quality of knowledge-based development. Additionally, although increased international scientific interactions and joint scientific and research activities with other countries of the world were mentioned in the plans, they have always been marginalised.

The government also released larger-scale and more significant documents to explain its plans. The use of large-scale policymaking in Iran is more recent than the medium-term planning. The oldest large-scale policymaking document in science and technology is Expediency Discernment Council's 
The future outlook of the Islamic Republic of Iran in the horizon of the next two decades, approved in 2003. This defines the 20-year horizon of the country's development.

The main goal of this vision document in science and technology was to achieve leadership for the economic, scientific and technological policies in southwest Asia, emphasising software development and science production (Expediency Discernment Council, 2003). This document formed the basis of the government's policy in 2003.

However, the most comprehensive reference for science and technology policymaking is the Supreme Council of the Cultural Revolution's Iran'sscientific comprehensive roadmap, approved in 2010. This map has specified the major strategies of the country's science policy and the priorities of Iran's science and technology in different areas of science and technology. Some of these priorities include aerospace, nuclear technology, biotechnology, nanotechnology and information technology. 'The promotion and simplification of scientific concepts' and the use of the media as a tool for 'transforming science into one of the main discourses of the society' were considered for the first time in this document. The media are proposed as a platform for knowledge transfer, to make up for the lack of public communication of science and technology by government and research organisations.

The latest document formulated by the Office of the Supreme Leader of the Islamic Revolution, in consultation with the Expediency Discernment Council, is General Policies of Science and Technology, which was announced to the heads of three judicial, executive and legislative powers in 2014. This brief and general document illustrates the major priorities of the government in the field of science and technology and is based on the idea of 'the Islamic Iranian progress model'.

The common feature of all the development documents and plans in Iran is that the government has always been the main executor (Godarzi et al., 2015): the part played by the private sector, industry and civil institutions in developing science and technology is negligible. These policies focus mainly on the development of tangible achievements of science and technology rather than providing the cultural prerequisites for development. The application of these policies has increasingly accelerated the publication of scientific papers in Iran, resulting in

the growth of scientific movements in the country, regardless of the needs of society, and sometimes as an independent entity disregarding the requirements of its peripheral environment. This has caused the science to fail to establish communication with decision-making, service and production systems. (Ghaneirad, 2003) 
The relationship between science and society in Iran has historically manifested four epistemological approaches: scientism, ideologisation and ritualisation of science, pseudo-positivist phobia towards the ideologisation of science and technology, and post-positivism (Farasatkhah, 2008). The scientistic approach believed in a stable place for science and excluded any influence of social and political conditions in scientific fields, and was dominant until the Islamic revolution. The ideological and ritualistic approach to science paid attention to the connection of social, political and cultural elements with science, showing its effects in the following decades in the projects of Islamicisation and localisation of science (ibid.). This approach was dominant in the postRevolution period. The reaction to the second approach (ideologisation and ritualisation of science) was that any discussion of local and indigenous knowledge was susceptible to suspicion and distrust (ibid.) within Iranian scientific communities. The post-positivist approach considers science as a sociocultural process linked with the interests of groups, loyalties and social and cultural factors within and outside the scientific community (ibid.). This approach was developed recently as a result of the globalisation.

Of these four approaches, the ideological and ritualistic approach to science has had a strong presence in the political and ideological arena. Specifically, the Leader of the Revolution has repeatedly criticised the extraction of science and technology, and in particular scientific and technological culture, from the Western world (Hasirchi and Niawand, 2011). According to him, the attention to development must be accompanied by the attention to spirituality (Supreme Leader, 2008) and the ultimate goal of the development of science and technology should be human salvation (Supreme Leader, 2010). Iran's scientific comprehensive road map has also been drafted with an emphasis on the Islamicisation of science and technology. In the General Policies of Science and Technology document (Supreme Leader, 2014), scientific and spiritual growth are always on the agenda of the policymakers as well as science issues. With the suggestion of the Leader of the Revolution, the Western concept of 'development' has been replaced by the term 'progress', and the concept of 'the Islamic-Iranian progress model' has been formulated. This model incorporates the perceptual foundations and the Islamic worldview. It puts forward the aspirations and desires to achieve progress based on the Islamic-Iranian identity. However, it has not provided a robust theoretical model for the realisation of these aspirations (Radmanesh and Taghavi, 2015).

Its effect has been an unbalanced attention to scientific fields, with some considered as strategic sciences (including tech-sciences such as ICT and nanotechnology), assuming that their content cannot be influenced by ideology or religion. The biggest influences of Islamicisation can be seen 
in humanities, which are more expected to promote Islamic attitudes and beliefs. In this situation, science communication can be considered closer to the strategic sciences.

A review of the process of science and technology policymaking in Iran shows that three groups of actors play a role with different levels of influence:

a. At the highest level, government and religious leaders (including the most influential legal entities or policymaking organisations) are responsible for formulating the upstream documents.

b. The intermediate level (senior officers in government departments) contributes to the formulation of the upstream documents and is responsible for formulating downstream documents, such as mid-term development plans or executive by-laws resulting from upstream documents.

c. Target groups (researchers, journalists, institutions) that are directly affected by the policies but rarely have a role in the policymaking process. However, they influence the implementation, realisation and formation of policies.

The institutions that carry out the activities of science communication and science promotion are not part of the process of science and technology policymaking, except for brief indications in the comprehensive scientific map of the country (Table 17.1).

\section{Table 17.1: Key actors of science and technology policymaking in Iran}

\begin{tabular}{|l|}
\hline Highest level policymakers \\
\hline Supreme Council of the Cultural Revolution; Expediency Council; Supreme Leader; \\
Supreme Council of Science, Research and Technology \\
\hline Medium level policymakers \\
\hline Science and Technology Deputy of Presidency; Science, Research and Technology \\
Ministry; State Management and Planning Organisation; Strategic Research Centre; \\
Ministry of Health, Treatment and Medical Training; Ministry of Education; Ministry of \\
Commerce, Mining and Industry; Ministry of Agriculture \\
\hline Target groups \\
\hline Universities, research institutes, science and technology parks, state organisations, \\
scientific associations, Islamic Republic of Iran Broadcasting, private science promotion \\
institutes, science clubs, knowledge enterprises, centres of excellence, media
\end{tabular}




\section{The practice of science communication in Iran}

Despite the lack of specific government policies for the development of science communication in Iran, science enthusiasts and experts have attempted to communicate with the community and have encouraged governmental institutions to build a relationship with the public. That is why the experience of science communication in Iran can be classified into the civil and governmental areas.

\subsection{Civil institutions, public sphere and science and technology communication}

The scientific community became interested sooner than any other institution in attracting the attention of the public to science. Specifically, the first scientific society of Iran, Physics and Chemistry Society of Iran, was formed in 1931 by a small group of physicists. The evolution of this society played an important role in public science communication.

Over time, promoting science and making the public aware of scientific achievements became the priority of the scientific community and science lovers. These pioneers established centres and foundations whose main mission was the establishment of the relationship between science and society. The most important examples are:

\subsubsection{Zirakzadeh Science Foundation}

Zirakzadeh Science Foundation was founded as a non-government and nonprofit institution in 1993 in order to promote science and technology. Its founder, Ahmad Zirakzadeh, sold his house before his death to provide the capital needed for this project. He believed that purely theoretical education was the most important weakness in the Iranian educational system (Dadar, 2010). In cooperation with municipalities, charitable institutions and people, as well as domestic and foreign experts, the foundation established exhibitions and halls of science and technology in Tehran and other cities. It also participated in setting up scientific centres in order to provide the opportunity for practical experiments and interactive learning of science for children and adolescents.

\subsubsection{The Home of Mathematics}

The first 'home of mathematics' in Iran was indebted to more than 20 years' experience of mathematics teachers' meetings on Monday afternoons. It was established in the form of a non-government institution in Isfahan in 1998. 
Its purpose was to promote mathematical knowledge and to generalise mathematical science. This venture was quickly expanded in other cities of the country (Scientific Associations' Reference, 2016).

\subsubsection{The City of Mathematics}

One of the Iranian innovations in promoting mathematics is the City of Mathematics. It was established in 1998 by Majid Mirzavaziri, professor at Ferdowsi University of Mashhad, to conceptualise mathematics with simple and attractive games for adolescents. The Mathballmatch (a game like football) and the Math Clinic (the detection of behavioural disorders through math games) are initiatives at the City of Mathematics. Other groups involved in similar activities include the Knowledge and Art Foundation, Amateur Branch of Astronomical Society of Iran, and the Iranian Association for Popularisation of Science and Technology Training Park.

\subsection{Science and technology activities supported by government and other groups}

Encouraging public interest and support for scientific policies is regarded by the government as one of the most effective measures to encourage scientific and technological development. That is why the prominent role of the government in many areas of science communication can be seen in Iran. Its most important activities are explained below (as well as those of other organisations).

\subsubsection{Academies}

Given that the non-Persian language of science was considered as an obstacle to its expansion into society, the First Academy was established in 1934. Its main task was to define the Persian equivalents for non-Persian scientific and technical terms. It helped people understand scientific texts. Today, the number of academies has increased in Iran, creating a space for developing new ideas for elites. However, the academies offer suggestions for major scientific issues that are highly complex as they are more in touch with elites than common people (Tayyebi, 2000; Roustaei, 2006).

\subsubsection{Institute for the Intellectual Development of Children and Young Adults}

The Institute for the Intellectual Development of Children and Young Adults was established in 1965 to develop the abilities of children and adolescents. It focuses on three activities: libraries, publishing organisations, and a cinema centre. With the establishment of mobile and fixed libraries, the institute tried to promote reading among children and adolescents in the early years following its founding. Novelty, attractiveness, simplicity and 
raising awareness were the main features of books written at the institute as they tried to persuade audiences to look more closely at world issues and get familiar with scientifically analysing them (Sharifi, 1998). The circulation of these books was high: 30-40,000 in 1969 and the minimum circulation was 10,000 volumes (ibid.). In 1970, a cinema centre was established at the institute to provide educational and entertainment films for children and young people (ibid.).

\subsubsection{Vice-Presidency for Science and Technology and Promotion of New Technologies}

According to the Iranian comprehensive scientific map, the promotion of new technologies such as nanotechnology, biotechnology and stem cells has become a priority. To develop and promote these technologies, to enhance the participation of interested groups, and to foster young talents, the VicePresidency for Science and Technology has launched a task force for their promotion and education. The jobs for this task force include holding seminars, workshops, festivals and national competitions aimed at providing appropriate cultural context and raising the awareness of the community and interested groups in these areas (Iran Biotechnology News Agency, 2018; Iran Nanotechnology Innovation Council, 2018).

To introduce nanotechnology, the Nano Task Force publishes a monthly journal, shows films, holds exhibitions and organises a nationwide nanotechnology week with the establishment of nano clubs in collaboration with education departments. The Biotechnology Task Force aims to establish a connection with five groups of audiences: students, scholars, professionals, managers and the general public who are consumers or members of the cycle of knowledge production, technology and industry. Its main purpose is to increase knowledge and technology acceptance among managers at various levels of government, investors and entrepreneurs, and to strengthen national pride. In the field of stem cells, the most important research institute, Royan, has called a part of its activities 'Stem Cells for Everyone'. By establishing mobile and fixed laboratories for the public, it has tried since 2011 to increase citizens' interest (especially students) in this field of study (Iran Biotechnology News Agency, 2018). Other groups involved in similar activities include the Ministry of Education, research centres, municipalities, science parks and science and technology museums.

\subsubsection{Awards and festivals of science promotion}

The Iranian Science Popularisation Award is the oldest award in the field of Iranian science promotion. It was founded in 1998 and has been the basis for the formation of the Iranian Association for Popularisation of Science. 
The association presents this award each year on World Science Day for Peace and Development. The award is given to individuals or organisations that have performed the best and most effective activities for the popularisation of science, the spread of scientific thought and culture in Iran, and the application of science at each level of social life (Iranian Association for Popularisation of Science, 2018). There are similar awards in science fiction, astronomy, etc.

\subsection{Media}

In general, science journalism from its beginning around 1900 has experienced an upward trend in quantity and quality, but there are challenges that have retarded its pace. First, economic fluctuations have caused difficulties for non-government scientific media. This has decreased the number of the pages and circulation rate of print media and has encouraged them to publish online. The second challenge stems from the lack of trust and legitimacy in the relationship between scientists and journalists. On one hand, scientists expect journalists just to reflect their voices, but on the other hand, journalists do not believe in scientists' ability to effectively communicate science to the public. The third challenge is related to the deficiency of professional science journalism education, which leads to a restricted science journalists' community who usually are self-taught or amateurs. This isolates the Iranian science journalists from global trends and developments arising in their careers. In the following paragraphs we will review the Iranian science journalism experiences on different media platforms.

\subsubsection{Radio and television}

The production of science TV shows began with the show Knowledge in 1968, with the aim of making people interested in and aware of scientific achievements. Iran's first science television channel (Channel 4) was launched in 1995 with the goal of reaching an elite audience and popularising science and technology. The Health Radio and the Health TV Channel were launched in 2003 and 2013 respectively, aiming to improve individual and social health and to popularise health issues.

The process of producing science shows has been slowly evolving in Iran. These shows, with the exception of TV shows called Night Sky and Pangan and a radio program called Scientific Talk, have not succeeded in attracting large audiences. 


\subsubsection{Documentary TV shows}

The science documentary TV shows produced in Iran are only related to the environment, wildlife and archaeology, and there are few spectacular, impressive or even good examples of these shows. The Growth International Film Festival, Scientific and Industrial Film Festival and Cinema Verite Festival are the only arenas available for the supply of science documentaries in Iran. ${ }^{1}$

\subsubsection{Journals}

The first Iranian public scientific journal is called Falahat Mozaffari, published by the Administration of Falahat (agriculture administration) since 1900. The purpose of this journal is to disseminate science, to modify methods of agriculture and cultivation, and to inform and raise public awareness. Two other public scientific journals are related to health and aim to promote applied sciences. Over the 119 years since the publication of public scientific journals in Iran, about 50 diverse journals have been published in various fields of science and technology (Ojagh, 2012). An analysis of the content of 144 issues of 12 series of the Iranian scientific journals demonstrates that medicine, psychology, animal sciences and technology, astronomy and nutrition sciences have enjoyed more coverage and have been often established and operated by specialists in the same disciplines (ibid.). Of course, the circulation of public scientific journals has not been high in Iran and their publication has been continued largely with the support of governments. More than anything else, the relationship between these journals and the public has been defined as educating good citizens, indicating the ability to use science to improve health, extend modern lifestyle, develop industry and solve socioeconomic problems. The journals have accordingly been dedicated to the celebration of science (Ojagh, 2012).

Interestingly, the first Iranian newspaper with a scientific identity was the Rooznameh Elmiye Dolat Ellie Iran (scientific newspaper of the Iranian supreme government), which began publication on 11 January 1864 (Hosseini Pakdehi, 1996). The founder of this newspaper, the Minister of Science and Education during the reign of Nasser-al-Din Shah Qajar, was himself a mathematician and an astronomer (Mohit-Tabataba'i, 1987). That probably is why the newspaper had a scientific character. With the proliferation of journalism, scientific pages became a regular part of many national newspapers and included information about new advances and

1 An interview with the producer of documentary shows and the researcher of science communication, Hossein Forotan, by Zarrin Zardar on 28 April 2018. 
discoveries, environmental crises, education and pseudoscience. With the development of communication with the Western world, the ratio of translated materials to produced ones has increased in newspapers.

\subsubsection{Public scientific books}

So far, a systematic study has not been conducted of these books as most of them have been translated from other languages, especially English. The history of science, the biography of scientists, and the concepts of basic science are common topics in public science books. In the field of storywriting, the most significant science fiction example, entitled S.G.L.L., was written by Sadegh Hedayat as a short story and published in 1932 . Here the writer portrays the future of the world using his imagination and science plays an important role. The oldest novel in science fiction is Rustam dar Garne Bist-o-Dovom [Rustam in the Twenty-Second Century], written by Abdol Hossein Sanatisadehin 1933, and it refers to future scientific advances.

\subsection{The importance of cyberspace in public science communication}

The internet, cyberspace and social networks have caused many changes in science communication. Their effects can be seen in three areas: first, the possibility of producing and publishing online news has led to the formation of news agencies and specialised channels of science and technology: the Science and Culture News Agency and the Telegram channel of Iran Science Watch are two examples. Second, the existence of the internet has led to the creation of virtual editorials and the publication of online public science journals such as Saros Astronomy Monthly (Saros, 2018). Third, science journalists have created scientific and technological events in the audiences' daily lives through blogging, video casts or podcasts.

\section{Science communication in the Iranian academic world: Research}

At the academic level, research in science communication is highly stressed. There is no independent education program in the field of science communication and it is only taught as a part of journalism or media studies programs at Iranian universities and research institutes. Under such circumstances, it is not unreasonable to say that education and research on science communication in Iran are not connected systematically to each other; therefore, improvements in research studies are dependent more on 
interested researchers than the pre-arranged academic research agendas. This issue leads to an unpredictable environment for research and education in the field of science communication.

In Iran, science communication was initially introduced by sociologists, and the first systematic study dates back to research conducted by Ghaneirad (2003). He analysed the relationship between science and social, political and economic systems. Today, four main fields of research can be identified:

\subsection{The social function of science communication}

This field of research examines the importance of science communication for society (Paya, 2008), and analyses the concept of literacy and ways to increase civic education in Iran (Ojagh and Vakil, 2013).

\subsection{Science and technology communication}

Studies conducted in this field can be divided into four sub-groups:

i. Measuring public understanding of science (Ghaneirad and Morshedi, 2011; Maher and Madaniyan, 2016; Shahriari, 2017). These studies, carried out on the citizens of Tehran and Isfahan, showed a low level of scientific knowledge of the public but also indicated that the public attitudes toward science are positive in Iran.

ii. Representing and covering science and technology on various media platforms. Examples of these studies include the identification of the criteria for the simplification of science and technology (Ojagh, 2012); the television representation of science and technology (Zardar, 2014; Tayyeb-Taher, 2016); the representation of science in the scientific pages of news agencies (Torabi, 2013); and the representation of various scientific topics in social networks (Bahram-Mirzai, 2017).

iii. The nature of the science communication process in Iran, within which one can refer to the process of science communication in Iran (Khaniki and Zardar, 2014); the study and identification of the model governing science communication in the Iranian public scientific journals (Ojagh, 2012); the description of the nature of the public science communication and its common theories (Ojagh, 2011); conceptual issues, methods and the importance of science promotion (Vesali and Ojagh, 2009); the structure of science communication in Iranian society (Sheikh-Jabbari and Ojagh, 2012); the explanation of the nature and necessity of public understanding of science (Vahidi, 2009; Frutan, 2011; Ojagh et al., 2013); the presentation of a theoretical concept for the establishment of effective science communication (Abdollahyan and Ojagh, 2014); the 
historical analysis of public science communication in Iran (Abdollahyan and Ojagh, 2013); the manner of translating and delivering public science texts (Ojagh, 2013); the study of the logic of content production in Iranian public scientific journals (Ojagh and Abdollahyan, 2014); and the study of the role of Iranian public scientific journals in increasing the public scientific understanding (Ojagh, 2012).

iv. Challenges and barriers facing science journalism (Bonyadi, 2015). Both the role of science journalism in simplifying and translating scientific concepts to society (Ojagh, 2019) and the functions of science journalists (Bonyadi and Borojerdi Alavi, 2016) are among the main research fields of science and technology journalism in Iran.

\subsection{Health communication}

A large number of researchers in the fields of social sciences, medicine and health have carried out studies in the health area. They have focused on physician-patient relationships (Shafati, 2012), health plans coverage (Ahmadi, 2012), and the status of health communication in Iran (Rasi-Tehrani and Atefimanesh, 2011).

\subsection{Policymaking in science and technology communication}

Reviewing the experiences of science and technology policymaking in the G8 $8^{2}$ and D- $8^{3}$ countries and comparing them with Iran (Vesali, Ojagh, Attari, $2007 \mathrm{a}, 2007 \mathrm{~b}$ ) is the first and most detailed work in this field. Some of these studies have also considered the network of relations between academic institutions and policymakers (Ghaneirad, 2004; Miremadi, 2013).

\section{Education in science and technology communication}

The first departments of science and technology communication, Science Promotion, Science and Society, and Politics of Science, Technology and Innovation, are active in the National Research Institute for Science Policy of Iran, educating students in a limited form in addition to training them to conduct research.

2 Group of Eight highly industrialised nations: France, Canada, Russia, Germany, Italy, United Kingdom, Japan and United States.

3 The Developing Eight is an organisation for development cooperation among Indonesia, Bangladesh, Egypt, Nigeria, Iran, Malaysia, Pakistan and Turkey. 
The science communication courses can be seen to some extent as lying within the syllabus of the academic discipline of communication. The science communication course at the undergraduate level at Tehran University and the science journalism course at the graduate level of the journalism major at Allameh Tabataba'i University are the only examples. However, the agricultural sector as a precursor cannot be ignored. Since the establishment of the Agricultural Research, Education and Extension Organisation under the supervision of the Ministry of Agriculture Jihad in 1974, all major universities in Iran have established the major of Agricultural Extension and Education in their faculties of Agricultural Sciences and Natural Resources. Tarbiat Modares University Press publishes a research journal with the same title.

Additionally, the establishment of new disciplines may indicate the interest of higher education institutions in this field. The major of Cognitive Science and Media, which has been approved at the Research Centre for Cognitive Science, is one of the first attempts to educate students in the field of science and technology communication. The UNESCO Science and Technology Communication Chair, launched at Allameh Tabataba'i University in 2017, pursues simultaneous research and educational goals (the establishment of new disciplines and short-term education courses) in this field.

\subsection{Science and technology communication journals}

The journals related to this field can be divided into three categories:

i. The journals relevant to communication and social sciences, which publish the results of studies of science communication scholars. Popularisation of Science is the only specialised journal in this field.

ii. In relation to the agricultural sciences, the journals Extension and Development of Watershed Management, Agricultural Extension and Education, and Agricultural Extension and Education Research publish specialised papers in this field.

iii. In relation to medical sciences, Health Literacy is interested in the publication of studies by researchers in medical sciences. In addition, there are a number of journals in health education and health promotion in Iran. Interestingly, there is no cooperation between these three categories, even in the publication of papers, indicating the lack of an interdisciplinary perspective on research, education and promotion of science communication in Iran. 


\subsection{Scientific conferences on science communication}

In recent years, the relationship between science and society has been considered in conferences. Two conferences were held in 2018: the National Conference on the Legacy of Science and Society organised by the Iranian National Science and Technology Museum, and the National Conference on the Academic System and Society organised by the Ministry of Science, Research and Technology and the National Research Centre for Science Policy.

\section{Discussion and conclusion}

This chapter presents a concise but comprehensive overview of the status of science communication in Iran at the three levels of policymaking, civil society and academia. As a review of the development documents show, science and technology communication was first noted in major policymaking documents in 2010. The most direct reference to public science and technology communication has been made in a comprehensive scientific map of the country. Making the language of science simple and intelligible has been taken into account more than anything else. The structure of science and technology policymaking in Iran focuses on the growth of science, regardless of providing necessary prerequisites of effective science communication (including public awareness of science and technology, public participation and engagement) in the public domain and civil institutions. There is almost no attention to the relationship between science and society at this time.

However, reviewing the experiences of science communication in Iran indicates that the government institutions at a micro level have some experience in science communication, and their activities are broadly diverse regarding subject as they cover a wide range in terms of geography. Despite the role of these institutions, the first practical efforts to develop science communication in Iran were made by civil institutions and interested people who sometimes engage in the institutionalisation of science communication with their personal funds. Mathematics, astronomy, information technology and physics are successful examples. However, what distinguishes the scientific communication experience in civil institutions from the government sector is the prospect of the activities of each of these sectors.

On one hand, civil institutions have shown a greater willingness to communicate with the outside world and have not confined the scope of their activities to the borders of the country. The idea of 'the sky without borders' hidden behind the Stars Peace Project or the idea of dialogue in the Good 
Wishes Project indicate this fact. On the other hand, they are making more effort to bring scientific subjects to the social arenas, and hints of the public involvement in science can be identified in their activities.

In contrast, despite the extensive activities and the availability of a greater budget, the government has focused on promoting scientific literacy through increasing awareness and education. Science communication has had less chance of engaging the audience in the realm of the government, thus much of the latter's activities can be explained by the transition model and the lack of public understanding of science. Given this evidence, it seems that in the field of science communication, civil institutions appear to be moving one step further than government structures even without supportive policies.

Reviewing media activities in Iran also indicates that the public scientific content of the media is quantitatively increasing. However, the translation and modelling of successful foreign samples still dominate the domestic creative products in all media platforms. The existence of the internet, of course, has led to the development of decentralised activities in the field of science communication, resulting in an unprecedented increase in content producers in the field of science and technology.

The review of academic activities also demonstrates that attention to science communication as a research area has a history of less than three decades in Iran. However, the interest in it has grown enormously in recent years, and numerous dissertations and research papers have been presented in this field. Science communication has also been considered in the arena of academic education and relevant academic disciplines have been established. In general, the development of science communication in Iran has been marked by a relatively long delay compared with the entry of modern science into Iran. However, it is now experiencing a rapid growth.

This widespread attention can be analysed from the perspective of developments in new technologies and policymaking insights. Indeed, despite the unique characteristics of Iran's media or structural status compared with many other countries in the world, Iranian society is part of the international community and is affected by global developments. The relatively broad and open space provided by the internet has strengthened the connection of Iran with the world. This is important in two respects: on the one hand, the Iranian public has access to an extensive source of information outside its national borders, causing their expectations of public scientific content to be defined based on global standards; and on the other hand, the providers of public scientific content can compare their priorities and practices with successful global models. Closer contact with the audience and moving to information-entertainment is one of the most important changes that the professional activity space has experienced in recent 
years. Therefore, the increased priority of science communication, particularly in such areas as environment, climate change and health have strengthened the status of science communication in Iranian society.

Policymaking affects the function of science communication for the state and government. Scientific fields, and in particular new technologies, are a competitive arena for countries around the world, and thus science and scientific progress have become an important part of the power discourse. The presentation of awards for scientific achievements has become a part of representing the image of governments to both the domestic and international public opinion. As a result, the growth of science communication to represent the image of scientific authority inside and outside the boundaries of the nation-state has become a necessity and has entered the area of science and technology policymaking and educational academic programs.

Therefore, a combination of global developments that increase civil society's capacities for the expansion of science communication and the need and willingness of governments to expand it indicate the clear potential for the expansion of science communication in Iran and its scientific community. Of course, the imbalance of forces and the lack of necessary links among the stakeholders of science communication in the country point to the danger that the expansion of quantitative and accelerated science communication may not necessarily lead to an increase in public participation and involvement in science. This is a concern that can be the focus of scholars' and experts' discussions in this field in Iran and beyond.

\section{References}

Abdollahyan, H. and Ojagh, S. Z. (2013). Calling to Audience By Science Communication Magazines. Culture - Communication Studies, 4(24), 7-24.

Abdollahyan, H. and Ojagh, S. Z. (2014). A Comparative Analysis of the Role of Iranian Public Science Magazines in Upgrading Scientific Knowledge of their Audience. Journal of Cultural Studies and Communication, 9(31), 43-62.

Abrahamian, E. (2008). A history of modern Iran. Cambridge University Press. doi.org/10.1017/CBO9780511984402.

Ahmadi, N. (2012). Picture of health in Iranian press: Comparative study of Health weekly and Tandorosti weekly (MA thesis). Allameh Tabataba'i University at Tehran, Iran.

Bahram-Mirzai, M. (2017). Communication and Environment in Social Networks (MA thesis). Allameh Tabataba'i University at Tehran, Iran. 
Bonyadi, F. (2015). Obstacles and challenges among science journalism in Iran (MA thesis). Allameh Tabataba'i University at Tehran, Iran.

Bonyadi, F. and Borojerdi Alavi, M. (2016). Function of science journalists in the press. Quarterly Journal of Iranian Association for Cultural Studies \& Communication, 12(43), 121-53.

Dadar, N. (2010). Khwaja Nasiruddin Tusi Hall of Science and Technology. Educational Technology, 26(1), 24-27.

Expediency Discernment Council. (2003). The future outlook of the Islamic Republic of Iran in the horizon of the next two decades.

Farasatkhah, M. (2008). Comparing three cognitive paths on 'domestic science' in Iran with emphasis on its conceptual, structural and functional change. Iranian Journal of Social Studies, 5(1), 97-110.

Frutan, H. (2011). A Study of the Concept of Science for Public (MA thesis). University of Amirkabir at Tehran, Iran.

Ghaneirad, M. (2003). Knowledge anachronism: Science relations with social-economic systems in Iran. Tehran: National Research Institute for Science Policy.

Ghaneirad, M. A. (2004). Science anachronism: Relationships between science and social systems in Iran. Tehran: National Research Institute for Science Policy.

Ghaneirad, M. A. and Morshedi, A. (2011). Survey of Public Understanding of Science and Technology, Pilot Study in Tehran. Journal of Science and Technology Policy, 3(3), 93-110.

Godarzi, M., Alizadeh, J., Gharibi, H. and Mohseni, M. (2015). Pathology of Science and Technology Policies of Iran: An Analysis of the five-year development plans. Journal of Technology Development Management, 2(2), 137-61. doi.org/10.22104/ jtdm.2015.184.

Hasirchi, A. and Niawand, A. (2011). Analysis of Islamic-Iranian Model of Progress from Supreme Leader's point of view. Journal of Basij Studies, 14(50), 51-82.

Hosseini Pakdehi, A. (1996). Take a look at the first Iranian scientific journal. Journal of System Management, 8(5), 30-37.

Iran Biotechnology News Agency. (2018). About us. Retrieved from biotechnews.ir/.

Iran Nanotechnology Innovation Council. (2018). About us. Retrieved from www. nano.ir.

Iranian Association for Popularisation of Science. (2018). Iran Science Promotion Award. Retrieved from www.popscience.ir.

Iranian Higher Education Research Institution. (2018). Iran's 2018 Higher education report. Institute for Research \& Planning in Higher Education. 
Iranian Physical Society. (2009). About us. Retrieved from www.psi.ir/.

Khaniki, H. and Zardar, Z. (2014). Science in the Media; Reconstruction of Science in Media Frames. Iranian Journal of Information Processing and Management, 29(4), 875-902. jipm.irandoc.ac.ir/article-1-2514-fa.html.

Maher, Z. and Madanian, S. (2016). Survey of Public Understanding of Science and Technology; Pilot Study in Isfahan, the First International Conference of Social Science and Sociology, Shiraz, 10 February.

Miremadi, T. (2013). The Role of the Analytical and Reflective Capacity in the Twin Processes of Technology Policy and Diplomacy: A Review of the Recent Development in the Process of Policy Making of Uranium Enrichment Technology in Iran. Journal of Science and Technology Policy, 6(2), 51-76.

Mohit-Tabataba'i, S. M. (1987). Iranian Press History (Persian edition). Be'sat, Tehran.

Mohsenian-Rad, M. (2013). Yearning for Proper Comprehension: Dar Hasrat Fahm-e Dorost (Persian edition). Simaye Shargh Tehran.

Office of the Supreme Leader of the Islamic Revolution. (2014). General policies of science and technology.

Ojagh, S. Z. (2011). An Overview of the Nature and Theories of Public Communication of Science. Popularisation of Science, 1(1), 24-31. Retrieved from www.popscijournal.ir/article_93351.html.

Ojagh, S. Z. (2012). Public Communication of Science and Technology in Iran: Mixed Method Analysis of the Role of Popular Science Magazines for Improving Public Understanding of Science (PhD thesis). Tehran University at Tehran, Iran.

Ojagh, S. Z. (2013). Translation to improve science literacy of public: Ignoring the Functionality in Popular science magazines. Translation Studies Quarterly, 11(41), 46-59.

Ojagh, S. Z. (2019). The changing role of science journalism in Iran. Journal of Culture-Communication Studies, 20(45), 103-26.

Ojagh, S. Z. and Abdollahyan, H. (2014). Understanding the Managerial Logic Used by the Iranian Public Science Magazines for the Production of Content. Journal of Iranian Cultural Research, 7(3), 25-43. doi.org/10.7508/ijcr.2014.27.002.

Ojagh, S. Z. and Vakil, H. (2013). Environmental Impact Assessment: Achieving Sustainable Development through Increased Civic Literacy. Popularisation of Science, 4(4), 19-27. Retrieved from www.popscijournal.ir/article_93157.html.

Ojagh, S. Z., Sheikh-Jabbari, M. M., Vesali, M., Zare, M. and Dorostian, A. (2013). On the essence and necessity of public understanding of science. Iranian Journal of Engineering Education, 4(56), 117-32. doi.org/10.22047/ijee.2013.3013. 
Paya, A. (2008). Public Understanding of Science: A Philosophical Appraisal. Journal of Science and Technology Policy, 1(1), 25-38. Retrieved from jstp.nrisp.ac.ir/article _12742_en.html.

Radmanesh, S. A. and Taghavi, M. (2015). Analysis of S\&T Section of the Bill of 'Islamic-Iranian Model of Progress' on the Basis of Islamic Requirements of Progress,. Journal of Science and Technology Policy, 7(3), 57-70. Retrieved from jstp.nrisp.ac.ir/article_12933_en.html.

Rasi-Tehrani, H. and Atefimanesh, R. (2011). Educational policy making on television. Social science monthly, 138(30), 126-36.

Roustaei, M. (2006). The History of The First Academy of Iran: Tarikh-e NakhostinFarhangestan-e Iran (Persian edition). Tehran: Nashr-e Ney.

Saros. (2018). About us. Retrieved from saros.ir/.

Scientific Associations' Reference. (2016). The history of Iranian Mathematical Houses Association. Retrieved from www.saref.ir/content-16-30=.

Shafati, M. (2012). A Sociological Analysis of the Doctor-Patient Interactive Relationship (A qualitative study in the city of Ahvaz, Iran) (MA thesis). Payame Noor University at Tehran, Iran.

Shahriari, P. (2017). Mediatisation of Science: The Role of media in Popularisation of Science (PhD thesis). Allameh Tabataba'i University at Tehran, Iran.

Sharifi, S. (1998). 'Institute for the Intellectual Development of Children and Young Adults 1965-1979'. Goftogu Monthly, (19), 2-37.

Sheikh-Jabbari, M. M. and Ojagh, S. Z. (2012). 'Structure of Communication of Science and Society in Iran: Popularising Science'. Science Cultivation, 2(2), 64-70. Retrieved from www.sciencecultivation.ir/far/pdf/sc04/4-8.pdf.

State Management and Planning Organisation. (1990). Islamic Republic of Iran's first economic, Social and cultural development plan.

State Management and Planning Organisation. (1994). Islamic Republic of Iran's second economic, social and cultural development plan.

State Management and Planning Organisation. (2000). Islamic Republic of Iran's third economic, social and cultural development plan.

State Management and Planning Organisation. (2004). Islamic Republic of Iran's fourth economic, social and cultural development plan.

State Management and Planning Organisation. (2017). Sixth Five-Year Plan of Economic, Social and Cultural Development of the Islamic Republic of Iran.

Supreme Council of the Cultural Revolution. (2010). Iran's scientific comprehensive roadmap.

Supreme Leader. (2008). Speech in presence of university students and professors. Retrieved from farsi.khamenei.ir/speech-content?id=5979. 
Supreme Leader. (2010). Speech at first summit of strategic thoughts. Retrieved from www.leader.ir/fa/content/7626/leader.ir.

Tayyeb-Taher, A. (2016). Comparing the observance of the principles of science journalism in the news section of IRIB and BBC1 (MA thesis). University of Islamic Republic of Iran Broadcasting at Tehran, Iran.

Tayyebi, F. (2000). History of the First Iranian Academy. Monthly Book of Literature, 38(2000), 105-7. Retrieved from ensani.ir/file/download/article/20120326165 305-3016-489.pdf.

Torabi, M. J. (2013). Content Analysis of Three Popular Iranian News Agencies (Mehr, ISNA and Jam-e-jam Online) in subject of Science and Technology in Six Months of 2011 (MA thesis). Islamic Azad University at Tehran, Iran.

Vahidi, M. (2009). Science-In-Society. Institute for Social and Cultural Studies, Tehran.

Vesali, M. and Ojagh, S. Z. (2009). Promoting Science: Conceptual topics, Methods and Importance. Rahyaft, 9(44), 62-7. Retrieved from rahyaft.nrisp.ac.ir/article _13481.html.

Vesali, M., Ojagh, S. Z. and Attari, M. (2007a). Conceptualising of Public Understanding of Science in Iran. Tehran: National Research Institute for Science Policy.

Vesali, M., Ojagh, S. Z. and Attari, M. (2007b). Monitoring and Studying of the National Policies in popularisation of science in G8, D8, India and China. Tehran: National Research Institute for Science Policy.

Vice President for Strategic Planning and Oversight. (2010). Fifth Five-Year Development Plan of the Islamic Republic of Iran.

Zardar, Z. (2014). Mediatisation of New Technologies in Iran: Cognitive Gaps of Main Actors in Representation of Biotechnology on TV (PhD thesis). AllameTabataba' $\mathrm{i}$ University at Tehran, Iran.

\section{Timeline}

\begin{tabular}{|c|c|c|c|}
\hline Event & Name & Date & Comment \\
\hline $\begin{array}{l}\text { First interactive science } \\
\text { centre established. }\end{array}$ & $\begin{array}{l}\text { Zirakzadeh } \\
\text { Foundation }\end{array}$ & 1993 & \\
\hline $\begin{array}{l}\text { First national (or large } \\
\text { regional) science festival. }\end{array}$ & $\begin{array}{l}\text { Popularisation of } \\
\text { Science }\end{array}$ & 1998 & \\
\hline $\begin{array}{l}\text { First university courses } \\
\text { to train science } \\
\text { communicators. }\end{array}$ & $\begin{array}{l}\text { The University } \\
\text { of Tehran }\end{array}$ & 2017 & $\begin{array}{l}\text { Bachelor's science } \\
\text { communication } \\
\text { degree }\end{array}$ \\
\hline $\begin{array}{l}\text { First master's students in } \\
\text { science communication } \\
\text { graduate. }\end{array}$ & Hossein Foroutan & 2011 & $\begin{array}{l}\text { He was an MA student } \\
\text { in Philosophy of } \\
\text { Science }\end{array}$ \\
\hline
\end{tabular}




\begin{tabular}{|c|c|c|c|}
\hline Event & Name & Date & Comment \\
\hline $\begin{array}{l}\text { First PhD students in } \\
\text { science communication } \\
\text { graduate. }\end{array}$ & Zahra Ojagh & 2012 & $\begin{array}{l}\text { From Cornell, as } \\
\text { a PhD student in } \\
\text { communication } \\
\text { sciences }\end{array}$ \\
\hline $\begin{array}{l}\text { First national conference in } \\
\text { science communication. }\end{array}$ & $\begin{array}{l}\text { The Heritage of } \\
\text { Science and the } \\
\text { Society }\end{array}$ & 2018 & $\begin{array}{l}\text { The main concept was } \\
\text { public communication } \\
\text { of science and } \\
\text { technology }\end{array}$ \\
\hline $\begin{array}{l}\text { National Science Week } \\
\text { founded. }\end{array}$ & $\begin{array}{l}\text { National Science } \\
\text { Week }\end{array}$ & 2012 & $\begin{array}{l}\text { Established by } \\
\text { Iranian Association } \\
\text { for Popularisation of } \\
\text { Science }\end{array}$ \\
\hline $\begin{array}{l}\text { First significant radio } \\
\text { programs on science. }\end{array}$ & $\begin{array}{l}\text { On geography, by } \\
\text { Radio Tehran }\end{array}$ & 1939 & $\begin{array}{l}\text { 1940: Ministry } \\
\text { of Culture, the } \\
\text { Department of Health } \\
\text { and the Department of } \\
\text { Agriculture produced } \\
\text { scientific texts for radio }\end{array}$ \\
\hline $\begin{array}{l}\text { First significant TV programs } \\
\text { on science. }\end{array}$ & Danesh [Science] & 1966 & By Esmail Mirfakhrai \\
\hline $\begin{array}{l}\text { First awards for scientists } \\
\text { or journalists or others for } \\
\text { science communication. }\end{array}$ & $\begin{array}{l}\text { National award for } \\
\text { popularisation of } \\
\text { science }\end{array}$ & Since 2011 & \\
\hline Other significant events & $\begin{array}{l}\text { UNESCO Chair on } \\
\text { Communication } \\
\text { of Science and } \\
\text { Technology }\end{array}$ & $\begin{array}{l}\text { Established } \\
\text { in } 2017\end{array}$ & \\
\hline
\end{tabular}

\section{Contributors}

Dr Seyede Zahra Ojagh is assistant professor in the Department of Cultural Studies and Communication at the Institute for Humanities and Cultural Studies in Tehran.

Dr Zarrin Zardar is an assistant professor of the Communication Sciences faculty at the Allameh Tabataba'i University, Tehran, Iran. She is the executive director of UNESCO Chair on the Communication of Science and Technology. 
This text is taken from Communicating Science: A Global Perspective, edited by Toss Gascoigne, Bernard Schiele, Joan Leach, Michelle Riedlinger, Bruce V. Lewenstein, Luisa Massarani and Peter Broks, published 2020 by ANU Press, The Australian National University, Canberra, Australia. 